\title{
PROJECT-BASED LEARNING IN PROMOTING LEARNER AUTONOMY IN AN EFL CLASSROOM
}

\author{
Yuyun Yuliani' \\ Nenden Sri Lengkanawati ${ }^{2}$ \\ Universitas Pendidikan Indonesia \\ yuyunyuliani69@gmail.com'; nendensl@indo.net.id ${ }^{2}$
}

First received: I May 2017

Final proof received: 27 September 2017

\begin{abstract}
In the Indonesian context, learning activities tend to be teacher-centered that a teacher still plays a dominant role in the learning process. Project-based learning is one of the approaches which is assumed to promote Learner autonomy. Since its implementation has not been effective, this study is aimed at investigating the current issue of how Projectbased learning promotes Learner autonomy in an EFL Classroom. This study employs descriptive qualitative research design at six participants of Junior High School students, grade nine. The qualitative data collected through document analysis, observation and interview were analyzed qualitatively. The results of data analysis led to a conclusion that project-based learning has promoted Learner autonomy, which covers the criteria of selfinstruction, self-direction, self-access learning and individualized instruction in each stage of Project-based Activity, namely the planning process, the implementation process and the monitoring process. There are also six important findings. Firstly, the learner autonomy varies among learners. Secondly, there is a linear relationship between learners' achievement and Learner autonomy. Thirdly, Learner autonomy needs process, and the process shows irregular patterns. Fourthly, it is worthy noted that no one is one hundred percent autonomous. Fifthly, among the three stages of the Project-based Activity, the learners gain the highest degree of Learner autonomy in the Implementation Process. Sixthly, there are still constraints in enhancing Learner autonomy. Due to the constraints above, this study recommends that promoting Learner autonomy needs support in some specific areas, especially the professional treatment of the teachers and institutions.
\end{abstract}

Keywords: learner autonomy; project-based learning; EFL classroom

In the Indonesian context most of the time, students' learning activities tend to be teacher-triggered or teacher-centered. It means that a teacher still plays a dominant role in the learning process. Therefore, it is found that the students do what the teacher says to do (Lengkanawati, 2016). In line with this finding, Rukim (2010) also agrees that some teachers in Indonesia still implement teacher-centered activities in which the teachers dominate the process of teaching and learning. They do not give opportunities for the students to develop their learning ability. The teacher is the only person who imparts knowledge or information to the learner. The learner is the receiver of the knowledge. As a result, the students do not have many chances to take parts actively in the learning process and to be responsible for their own learning.

Referring to the issue above, it is obvious that the teacher-centered activity does not give opportunities for learners to be more independent in the learning process. Therefore, there should be a solution to this problem. The teacher has to find the technique or method which gives the learners more opportunities to be more independent in the learning process. It means that both the teacher and the learners have to be aware of the importance of being autonomous in learning. The teacher has to facilitate the learners to be responsible in determining matters for their learning, such as the objectives, the learning activity, the material resources, the assessment technique and reflection. In other words, the teacher must encourage the learners to be actively involved in the learning process so the learners can promote their learner autonomy.

The term learner autonomy is defined as 'the ability to take charge of one's own learning' (Holec, as cited in Barillaro, 2011). In other words, it refers to the learning activities which give the learners more opportunities to determine the objectives, to define the contents and progressions, to select methods and techniques to be used, to monitor the procedures of acquisition and to evaluate what has been acquired (Holec, as cited in Balcikanli, 2010). Learner autonomy is a very crucial idea because it gives more opportunities for the students to be independent in learning. The indication of learner autonomy can be elaborated by determining how good the learners are in fulfilling the criteria of 
learner autonomy, which covers self-instruction, self-direction, self-access learning and individualized instruction (Dickinson, as cited in Kumaravadivelu, 2003). The more the criteria are fulfilled, the higher learner autonomy is.

By having learner autonomy, many advantages can be yielded in the learning process. As proposed by Dickinson (Dickinson, as cited in Kumaravadivelu, 2003), through prolonged process, the learners master 1) self-instruction, which refers to a situation in which learners are working without the direct control of the teacher, 2) self-direction, which means situations in which learners accept responsibility for all the decisions concerned with learning, 3) self-access learning, in which learners make use of self-access teaching material or instructional technology and 4) individualized instruction, which refers to situations in which the learning process is adapted, either by the teacher or by the learner, to suit the specific characteristics of an individual learner. Mainly, by implementing learner autonomy, the learners have more opportunities to be autonomous in learning, even in life.

As mentioned above that by implementing learner autonomy, the learning process changes from teacher-centered to student-centered learning. Actually, teacher-centered is not totally useless. There is still advantage of it. However, so far as it is implemented in Indonesia's classroom activity, teacher-centered activities minimize the opportunities of the learners to be autonomous (Lengkanawati, 2016; Rukim, 2010). In fact, this condition occurs not only in Indonesia but also in other countries. Kesli (2015) reports that in Turkey, the learning process still implements teacher-centred activities. He adds that the only meaningful interaction in the target language is the drills provided by the teacher, because students do not actively take part in classroom activities, especially in reading comprehension. Moreover, there is little interaction among teachers and students. The teacher usually spends a great deal of time speaking and explaining to the class; while students are required to sit passively and listen to the teacher attentively. Similarly, Wang (2010) states that the teachers who implement teacher-centered activities believe that their main duty and activities are to transfer their knowledge to the students. Thus, the only interaction allowed to occur in the classrooms is examinations or quizzes in which students have to answer the specific questions given by the teacher.

Reviewing the conditions of English instruction in different countries above, the teacher-centered activity definitely gives less opportunity for the learners to manage their own learning. It yields nothing but the dependence of the students to the teacher. The learners do not master strategies to handle problems during the learning process. To be worse, Mullis (as cited in Lengkanawati, 2016) stated that the students will not be able to reach higher order thinking skills which are important to handle complex problems in their daily life. Concerning this unexpected fact, teachers have to change their mind. They have to implement a learning method which gives independent learning opportunities as much as possible for the learners. Hence, they can enhance their learner autonomy.

In the last decades, the term learner autonomy in language learning has been a topic of interest for many researchers (e.g. Balcikanli, 2010; Barillaro, 2011; Barnard, 2014; Benson, 2012; Borg and Al Busaidi, 2012; Gardner; 2011; Kamberi, 2013; Kim, 2014; Lengkanawati, 2016; Dam, 2008; Ramirez, 2014; Rao, 2012; Shahsavari, 2014). The previous research above investigated how some strategies of learning, such as portfolios, student's journal or student's log, technology-based learning and project-based learning, promoted learner autonomy. The findings indicated that the implementation of the learning strategies mentioned above improved learner autonomy. Nevertheless, there are many constraints in implementing it, because it is not an easy work. Therefore, Lengkanawati (2016) states that to be successful in learner autonomy, it needs the commitment of the teachers to make their duty a major factor in its success.

Being motivated by the advantage of learner autonomy in the learning process and the success of the previous research, this study investigates how learner autonomy promotes the learning process, especially by implementing project-based learning. The project was a role-play and carried out in groups. It lasted for about one month and consisted of three stages, planning, implementation and monitoring stages. In every stage, this study reveals how the learners in the group promote learner autonomy, which is represented by the mastery of the four criteria, namely self-instruction, selfdirection, self-access learning and individualized instruction (Dickinson, 1987, in Kumaravadivelu, 2003, p.132). This study attempts to carry out a similar research by Ramirez (2014) but in different context.

\section{METHOD}

This study employed the descriptive qualitative research design to answer the statement of the problem aforementioned. This method is generally aimed at revealing a comprehensive summary or complete description on phenomenon happening during the intended treatment (Thorne, 1997; Sandelowski, 2000; Lambert and Lambert, 2012). The purpose of this study was to reveal and to gather evidence whether project-based learning could enhance students' learner autonomy in an EFL classroom.

By employing this research design, It was specifically intended to reveal a comprehensive 
information and a complete description of an authentic phenomenon concerning how projectbased learning can promote learner autonomy, especially viewed from the four criteria of learner autonomy mastered by the participants, namely selfinstruction, self-direction, self-access learning and individualized-learning. In other words, this study investigated every phenomenon happened when the participants carried out every stage of project-based learning, then it identified the criteria of learner autonomy which had been promoted by the participants during the learning process.

\section{Research sites and participants}

This study was conducted to the ninth grade students in one public junior high school in Bandung, Indonesia. It employed purposive sampling by selecting the participants from students on purpose (Gay, Mills, \& Airasian, 2009; Silverman, 2005). The participants were taken from three levels of students' achievement, namely the low, middle and high achieving students. Each level consisted of two students. So there were six participants. The selection of the participants was based on their achievement in the last semester and based on the recommendation of the home teacher and counseling teacher. The number of participants was determined based on the assumption that they represented each level of competence and they would give sufficient information for data collecting purpose. By selecting two students in each level, this study expected that it could compare each other in analyzing the data, so it could draw a conclusion properly.

\section{Procedure of Collecting Data}

This study employed four types of instruments including students' journals, observation by the teacher, observation by peer and structuredinterview.

Students' journals were collected after the students had done the three stages of the project. The first journal was written after stage 1, namely planning the project. Planning the project covered at least three activities: determining the group's name and the topic of the role-play, determining the schedule of group-work, discussing the steps of doing the project and the role of each group member. The second journal was written and submitted by the students after stage 2 , in which the students carried out the project. This stage included carrying out the project based on the schedule, accessing the material from various sources, determining the costumes and properties, and practicing with group members both inside and outside the classroom. Finally, the third journal was written after stage 3 . It covered communicating the project in front of the class, discussing the strength and the weaknesses of the group work and recommending any idea for the group in order to be better in the future (reviewing/monitoring and reflection of the project). One student had to submit one journal which elaborated matters concerning what he had done during the project. So every student would submit at least three journals during the project. The journal was handwritten and written in Indonesian because it made the students express their words more easily and it would avoid misunderstanding between the teacher and the students in the process of analyzing the data. For the sake of this research, this study would only analyze the journals written by the six research participants, who represented the low-achieving students, the middle-achieving students and the high-achieving students. After collecting the journals, the teacher read them, then identified and classified each activity based on the criteria of Learner autonomy proposed by Dickinson (as cited in Kumaravadivelu, 2003).

Classroom observation was conducted during the teaching process. It was aimed at observing and understanding the natural environment as lived by the participants without altering or manipulating it (Gay et al., 2009). In this study, classroom observation was held not only by the teacher but also by the peer. Both were addressed to complete each other so the writer got valid data. It was particularly aimed to explore three phenomena: to explore what the students do in the planning stage of the project, to explore what the students do in carrying out the project, and to explore what the students do in reviewing and monitoring stage of the project. Observation was conducted three times every week during the class reviewing. So there were six observation results: three of them were done by the teacher and the rest were done by the peer. The first observation was conducted during the planning stage. The second observation was conducted during the implementation stage. The third observation was conducted after the reviewing or monitoring stage. The observation concentrated on how the participant fulfilled the four criteria suggested by Dickinson (as cited in Kumaravadivelu, 2003): self-instruction, selfdirection, self-access learning and individualizedinstruction.

The interview was a purposeful interaction in which one person obtains information from another. This study employed structured interview, which consisted of a specified set of questions that elicited the same information from all respondents (Gay et al., 2009). It was conducted face to face three times during the project. The first interview was conducted after planning stage. The second interview was conducted after the implementation stage. The third interview was conducted after the reviewing or monitoring stage. The interview explored how the participants fulfilled the criteria of Learner autonomy above. For the sake of this research, the writer only analyzed the interview result of the participants. During interviews, field 
notes were taken and interview records were taken. The objective was to obtain additional data which were inaccessible through journal and observation. It functioned as complementary data.

\section{Data Analysis}

The data collected were analyzed to describe the effectiveness of project-based learning in promoting learner autonomy. The data were gathered from the triangulation of the students' journal, observation and interview. The data analysis included a content analysis of students' journal, notes from the observation (both by the teacher and by the peer), interview transcript and notes on interview content.

The first stage in data analysis was analyzing the students' journal. The researcher employed three steps: reading/memoing, describing what was going on in the setting, and classifying research data (Gay et al., 2009). After collecting the students' journal, the researcher analyzed through several stages. The first stage was identifying students' autonomy, which is stated by the students in their learning journal and classifying the findings based on the criteria of learner autonomy proposed by Dickinson (as cited in Kumaravadivelu, 2003). For detailedinformation, the analysis covered the three stages of project-based Learning, namely the Planning Process, the Implementation Process and the Monitoring Process of Project-based learning. The second stage was making meaning of the findings based on the criteria of learner autonomy proposed by Dickinson above. The third stage was identifying various aspects of criteria mastered by the students in each stage of project-based learning to determine the degree of learner autonomy.

Observations were held not only by the teacher but also by the peer students. This was attempted to gain a complete data in case the teacher's observation is insufficient. So the observation results could complete each other. The data of classroom observation were supported by field notes. After each teaching and learning process, the field note was analyzed to get information about the students' activity in the classroom. The researcher focused on the students' activities during the project. The information was also supported by a field note that was written soon after the meeting by the peer. The activities in the classroom were categorized based on research questions. There were four steps in analyzing the data of classroom observation: 1) analyzing observation notes of the learning process, 2) summarizing all activities during the learning process which were relevant to the study and matching data with the research questions, 3) coding and categorizing the data based on the four criteria of learner autonomy, and 4) identifying various activities mastered by the students to determine the degree of learner autonomy. The result of observation and interview results were synthesized in the report of the learning process to be cross checked with the data from students' journal.

The data from interview were analyzed in several steps, as proposed by Gay et al. (2009). First, the data were transcribed and converted in writing forms. Then, they were categorized and interpreted to answer research questions. The transcripts were then read, paraphrased and abstracted into briefer statement to get the main idea. Next, the data were coded and categorized based on the four criteria of learner autonomy. Finally, the interview was interpreted based on the learner autonomy criteria in order to complete the existing data gained from the results of students' journals and observations. After the data gained from the journal, observation and interview were analyzed, this study formulated the analysis results to draw conclusions and give recommendations.

\section{FINDINGS AND DISCUSSION}

In order to answer the research questions and to achieve the purpose of this study, the findings to be the center of discussion are learner autonomy, which could be acquired and enhanced by the students through project-based learning in an EFL classroom. To provide a clear presentation, the research findings on learner autonomy are discussed according to both of their theoretical and practical implications under the following main headings: (1) learner autonomy in the planning process of projectbased learning, (2) learner autonomy in the implementation process of project-based learning, and (3) learner autonomy in the monitoring process of project-based learning.

\section{Learner Autonomy in the Planning Process of Project-based Learning}

In the planning process of project-based learning, it is found that basically most students have fulfilled the criteria of learner autonomy, namely selfinstruction, self-direction, self access learning and individualized instruction.

\section{Self-instruction in the Planning Process of Project-based learning.}

In terms of self-instruction, it is found that generally the participants actively involved in determining group's name, determining the topic of the roleplay, arranging schedules and role sharing. These findings are consistent with the findings of related literature in that the learners mainly work in groups without the direct control of the teacher (see Kamberi, 2013; Kim, 2014; Ramirez, 2014; Rao, 2012). Besides the advantages, there are also constraints faced during the planning process. In case of two learners who did not take part at all in the planning process, they obviously did not fulfill the criteria of self-instruction. These findings are in line with the findings which have been elaborated in the related research. They do not understand the 
importance of developing learner autonomy, lack the skill to learn independently, and are not accustomed to being asked to take responsibility for their learning (see Borg \& Al Al Busaidi, 2012; Lengkanawati, 2016). The learners are lazy and lack the determination in English learning (see Rao, 2012). The learners' limited proficiency in English also causes them do not fulfill the criteria of selfinstruction (see Lengkanawati, 2016).

Despite the possession of self-instruction in the planning process, some specific items of selfinstruction have not been well acquired by the learners. The degree of self-instruction of learner autonomy varies among six learners. Two learners do not fulfill at all (0\%). Two learners fulfill $50 \%$ of self-instruction. One learner fulfilled $75 \%$ and one learner fulfills $100 \%$. These findings are in line with the results of the study by Sinclair (as cited in Simon \& Al Busaidi, 2012). It is mentioned that there is no one who is one hundred percent autonomous. He may be more or less autonomous in one thing to another thing which shows the degrees of autonomy. It shows that the degree of learner autonomy varies.

\section{Self-direction in the Planning Process of Project- based learning.}

Based on Dickinson (as cited in Kumaravadivelu, 2003) self direction refers to the idea that the learners are responsible for their learning. Basically, all the learners have responsibility for their learning and they have fulfilled the criteria of self-direction. These findings are in accordance with those which are formulated in the previous related research (see Ramirez, 2014; Rao, 2012). Moreover, during the planning process, the learners demonstrated autonomy in language learning, autonomy in learning and autonomy in life which reveal their responsibility (see Benson, 2012). The criteria of self-direction, in fact, varies from one to another. Mostly, the learners are responsible and get involved actively to determine matters during the planning process. Some learners are responsible by attending the groupwork attentively, but they are passive. They accept the other group members' decision. However, their cooperation yields good relationship and product. These findings are in line with the findings of previous research that learner autonomy can be developed by means of cooperative work in order to achieve common interests and support each other (see Ramirez, 2014).

\section{Self-access learning in the Planning Process of Project-based learning.}

Self-access learning refers to situations in which learners make use of self-access teaching material or instructional technology that is made available to them (Dickinson, as cited in Kumaravadivelu, 2003). During the planning process, most of the learners did not make use of various materials. Only one learner accessed internet for the dialogue text. The findings lack of information about self-access learning because at the beginning of the project, the learners still adapted to each other. They still focused on preparing and scheduling the next steps. This finding is in accordance with the aspect of learner autonomy suggested in the previous research (see Sinclair, as cited in Simon \& Al Busaidi, 2012). The aspect elaborates that the learners' autonomy is not an innate quality or ability that someone is born with. It is something that someone can learn through a prolonged process. So, the learners need long process to fulfill the criteria of self-access learning.

\section{Individualized-instruction in the Planning Process of Project-based learning.}

Individualized instruction refers to situations in which the learning process is adapted, either by the teacher or by the learner, to suit the specific characteristics of an individual learner (Dickinson, as cited in Kumaravadivelu, 2003). During the planning process, the learners had not yet shown this criteria of learner autonomy because they still discussed about the preparation for the next steps.

\section{Learner autonomy in the Implementation Process of Project-based learning}

The activities in the implementation process of Project-based learning cover doing the project based on the schedule, searching for the material from various sources, determining the costumes for the role play, and practicing both in the classroom and outside the classroom.

\section{Self-instruction in the Implementation Process of Project-based learning.}

During the implementation process, the learners have generally fulfilled the criteria of selfinstruction. They worked in groups without the direct control of the teacher. All learners were involved in all activities, such as doing the project based on the schedule, searching for the material from various sources, determining the costumes for the role play and practicing both in the classroom and outside the classroom. These findings are in line with those in the previous related research (see Ramirez, 2014). The learners succeed in making the dialogue, and have concrete opportunities to put the language into practice when doing it and sharing the work they have done over a month.

Although the learners still face the problem of the group-work, they were still able to cooperate with each other in the group and control the process. These findings are in line with what Ramirez (2014) proposed that cooperative work also has a positive influence on the increase of learner autonomy to discuss and exercise more choices and control over their learning process. Despite the mistakes during the implementation process, they still worked in 
harmony. These findings are in accordance with Ramirez (2014). He found that the learners can interact and learn from their own mistakes whenever they are given meaningful choices and control of their learning. As results, the learners are confident enough to control their own learning and they chose beneficial ways to improve their own learning in the classroom.

\section{Self-direction in the Implementation Process of Project-based learning.}

Self-direction refers to situations in which learners accept responsibility for all the decisions concerned with learning. (see Dickinson, as cited in Kumaravadivelu, 2003). Generally, most learners have fulfilled the criteria of self-direction. They are responsible to their learning during the implementation process. They carried out all activities including doing the project based on the schedule, searching for the material from various sources, determining the costumes for the role play and practicing both in the classroom and outside the classroom. These findings are similar to Ramirez (2014). In this stage, the study shows how intrinsic motivation implies the desire for accomplishment and knowledge to fulfill a learning goal. The results of this study show that most learners were aware of self-monitoring and self-evaluation strategies such as evaluating their progress and attempting to understand the reasons behind their mistakes.

In case of a learner who was not responsible for the group work and did not fulfill the criteria of self-direction of learner autonomy, the findings reveals that he prefers that the teacher determines the group's rules so he will sincerely obey them. These findings are in line with Borg and Al Busaidi (2012). They elaborate that most problems come from learners. They do not understand the importance of developing learner autonomy, lack the skill to learn independently, and are not accustomed to being asked to take responsibility for their learning. Similar idea also stated by Lengkanawati (2016) that there are constraints that could prevent teachers from developing learner autonomy. One of them is students' lack of autonomous learning experience. Our students have too long experienced what is referred as a spoon-fed method and are not accustomed to be autonomous.

\section{Self-access Learning in the Implementation Process of Project-based learning.}

Self-access learning refers to situations in which learners make use of self-access teaching material or instructional technology that is made available to them (Dickinson, as cited in Kumaravadivelu, 2003). Basically, the ability of the learners to make use of various material resources varies. Some students have accessed the material resources autonomously but some of them have not. They searched for the material from the internet, mainly from Google Translate. These findings are in line with Kim's finding (2014) that the use of technology or other resources helps the students build learner autonomy successfully.

However, some learners did not access the learning materials and they attended the group-work passively. These findings are similar to the findings of the previous research by Rao (2012). These constraints emerge because they are simply not ready to devote enough time and energy to English learning at all. Students' lack of autonomous learning experience also caused the constraints related to the ability of self-access learning (see Lengkanawati, 2016). To cope with these constraints, the teacher have to motivate and facilitate the learners attentively or to put them in a group, in which those who do not have a high level of self-access learning can implement strategies such as working in teams, using dictionaries, reading, listening to music in English, and watching TV (see Ramirez, 2014).

\section{Individualized-instruction in the Implementation Process of Project-based learning.}

As for individualized-instruction, the learners adapt their learning process, either by the teacher or by the learner, to suit the specific individual characteristics. The findings show that every learner takes different way when he/she attempts to accomplish the task. All learners indicate their individual way of learning in order to carry out the task well. Some of them memorized the dialogue, did the task according to the schedule and accessed the material resources. Despite their differences, they worked together in harmony. These findings are in accordance with Ramirez (2014), who elaborates that cooperative work also has a positive influence on the increase of learner autonomy to discuss and exercise more choices and control over their learning process. It fosters a high degree of autonomy because this type of work gives learners the freedom to explore their own preferences and to decide what activities are best for accomplishing their common goals.

\section{Learner autonomy in the Monitoring Process of Project-based learning.}

The monitoring process is the last process in the project-based activity in which the learners communicate their project, both in spoken and written language. Then, they monitor and evaluate the previous activity during the project as well as recommend what the next project looks like. There are three stages in the monitoring process of Projectbased learning: communicating the task in front of the classroom, discussing the strength and the weakness of the group work during the project and recommending the next project.

\section{Self-instruction in the Monitoring Process of Project-based learning}

In general, all learners intentionally communicated the task in front of the class. They developed their 
language competence, especially speaking. The speaking competence varies from one to another. Among all learners, the first low achieving learner looked unconfident. He did not master the dialogue nor proper expression. On the other hand, other learners looked confident. They mastered the dialogue appropriately and expressed the utterance with good expression. They autonomously develop their language competence without the teacher's control. These findings are in accordance with the findings formulated by Rao (2012) and Ramirez (2014). In this case, the learners enhance active learning and are encouraged to have a comprehensive development in language skills. They are self-motivated to improve their English by implementing particular learning strategies. Communication in English is one of the most important effects of this research project. Despite the fact that students still make mistakes and do not achieve the highest level of proficiency, they have concrete opportunities to put the language into practice when communicating the dialogue in front of the class, and sharing the work they have done over the course of the month. The project increases learner autonomy to discuss, exercise and control over their learning process.

During the group work, the learners discussed the strength and the weakness of their performance both directly and indirectly. In discussing the weakness, some learners said that they were not accustomed to write journals so they found it difficult. Some of them realized that the group was not in harmony, so they could not cooperate well. Not all group members studied hard to memorize the text dialogue so the role play was not interesting. Despite all the weakness, the learners found the strength during the group work. Generally, they learned much from the group. They felt happy and developed warm relationship, like a family. These findings are consistent with the previous research that during the project, learners display selfregulation in regard to facing failures through learning strategies. Furthermore, most learners are aware of self-monitoring and self-evaluation strategies such as evaluating their own progress (see Ramirez, 2014).

During the monitoring process, all learners also proposed some recommendations for the next project based on their perspective, without teacher's control. This shows that their self instruction have developed. The recommendations emerge as they feel different ways of learning strategy from what they used to do (from expositorical activity to project-based learning). The recommendations reveal how the project should be, particularly in determining group member, the theme, schedule, material, role-sharing, costumes, rules and punishment. The learners classify the matter into three: the group's part, the teacher's part, and the agreement between teacher and group. The group's part covers determining the theme, the material, the role-sharing and the costumes. The teacher's part includes determining the rules and punishment. Meanwhile, determining group member and schedule had to be discussed and determined both by teachers and group. The findings are consistent with the findings of previous research that projectbased learning gives opportunities for the learners to show how intrinsic motivation implies the desire for accomplishment and knowledge to fulfill a learning goal. Most learners are aware of self-monitoring and self-evaluation strategies such as evaluating their progress and attempting to understand the reasons behind their mistakes (see Ramirez, 2014). The findings also show that the learners are not able to manage all the learning process themselves. They think that some parts of the learning process have to be controlled by the teacher. These findings are also in accordance with the previous research (see Shahsavari, 2014), that most of the students expect their teachers to play the main role in the class and if the teacher tries to hand over some part of this responsibility to students, they think he or she is not an active or well-experienced teacher.

\section{Self-direction in the Monitoring Process of Project-based learning}

Self-direction reflects whether or not the learners are responsible for the project. During the monitoring process, self-direction is shown by the learners when they prepared themselves to communicate the dialogue. The preparation took relatively long time, starting from the planning process to the implementation process. Generally, most of the participants have good responsibility to do the group task, especially when they have to perform the dialogue in front of the class. Ramirez (2014) argued that the learners assume the responsibility for taking an active role during the project, in order to direct their learning responsibly to promote learner autonomy.

There was, however, one learner who was lazy during the monitoring process and irresponsible for the task. It was also found that he did not carry out every step of the project-based learning well. It was indicated by his inability to master neither the text of the dialogue nor produce good facial expressions. He looked very nervous and unconfident. These are caused by insufficient preparation. He lacks selfmotivation and has low levels of learner autonomy from the very beginning of the project. Eventually, he performed badly during the project. These findings are in accordance with Lengkanawati (2016) who elaborated that student's lack of autonomous learning experience may be one of the constraints which burden the process of learner autonomy.

\section{Self-access learning in the Monitoring Process of Project-based learning}

The indication of learners' attempts concerning selfaccess learning during the monitoring process is not 
as much as that in the implementation process because the learners came to the last stage after struggling in the previous stages. Some learners, especially the middle and high achieving learners, still intentionally accessed the material resources to check up the English word pronunciation before they performed the dialogue. They searched for the right pronunciation in Google Translate and dictionary. As Ramirez (2014) explained, these findings suggest that project-based learning, enhances the students' interest to access the learning material from different resources. In other words, project-based learning gives learners the freedom to explore their own preferences.

While for the low-achieving learners, the findings reveal that they stopped searching, or even were not interested in doing it because they had low levels of learner autonomy. In line with Lengkanawati (2016), students' lack of autonomous learning experience - in addition to limited time allotted in their curriculum, too much focus on examination and students' limited proficiency in English - is constraints that could prevent teachers from developing learner autonomy. She suggests that to handle the constraints above, the teachers must be able to access to various learning resources which could be beneficial for the students.

\section{Individualized-instruction in the Monitoring Process of Project-based learning}

The participants' individualized instruction is reflected in the way the learners prepared for communicating the project. In their attempt to master the dialogue well, some learners employed various learning process. Given more opportunities to be autonomous, the learners chose their own method which they thought more convenient and easier to carry out in order to gain the goal effectively. It suggests that cooperative work in project-based learning foster a high degree of autonomy because it gives learners the freedom to explore their own preferences and to decide what activities are best for accomplishing their common goals (Ramirez, 2014). Through project-based learning, the learners can learn particular thing based on their learning style (visual, auditory or kinesthetic), preferable time (at night or at dawn), either individually or in groups. In brief, learners can behave more autonomously when the teacher provides learning opportunities in which students are actively engaged in the development of each activity proposed in the classroom.

\section{CONCLUSION}

Answering the research question of the current research about how the learners promote learner autonomy through Project-based learning, it comes to a conclusion that project-based learning promotes learner autonomy. The indication is that most research participants fulfill the criteria of selfinstruction, self-direction, self-access learning and individualized-instruction in every stage of Projectbased learning, namely the planning process, the implementation process and the monitoring process.

There are also six important findings. First, the learner autonomy varies among learners. Second, there is a linear relationship between learners' achievement and learner autonomy. Third, learner autonomy needs process, and the process shows irregular pattern. Fourth, it is worth of notice that no one is one hundred percent autonomous. Fifth, among the three stages of the project-based activity, the learners gain the highest degree of learner autonomy in the implementation process. Sixth, there are still constraints in enhancing learner autonomy.

Regarding autonomy in an EFL classroom through project-based learning, not all students have developed a positive attitude towards it. Mostly, they are accustomed to being spoon-fed by the teacher. As a result, some of them become passive learners. For improving learner autonomy, it is suggested for the teacher to keep encouraging the students to realize that project-based learning can improve learner autonomy. Thus, the teacher has to motivate and facilitate the students to carry out the task willingly and completely. It is worth noting that both the teacher and the students have to have a commitment to carry out learner autonomy. They can share their role at the beginning of the project. Last but not least, the success of promoting learner autonomy depends on the institution policy which facilitate the learning process. That is why, the school system also has to be managed as well as possible to promote learner autonomy.

Nonetheless, the study leave some gaps for further study. As the findings of the current study are only based on one kind of project, role-play, they might not valid for other projects considering that every project has different nature. In addition, the participants are limited in number because there were only six learners. It is assumed that the more participants involved, the more findings the study is likely to be acquired. Moreover, the participants do not vary because this study only investigated the participants from one level (the ninth grade learners of Junior High School). Finally, in findings and discussion, this study limits them based on the criteria of learner autonomy proposed by Dickinson. It is possible that further research investigates them from other theorists as benchmarks.

\section{ACKNOWLEDGMENT}

Universitas Pendidikan Indonesia, particularly English Education study program is gratefully acknowledged for supporting the research. 


\section{REFERENCES}

Balcikanli, C. (2010). Learner autonomy in language learning: Student teachers' beliefs. Australian Journal of Teacher Education, 35(1), 90-103. Retrieved on March 12, 2015 from http://ro.ecu.edu.au/ajte/vol35/iss 1/8.

Barillaro, F. (2011). Teacher perspectives of learner autonomy in language learning (Master's dissertation), TESOL Centre, Sheffield Hallam University, Sheffield, England.

Barnard, R. (2014). Learner autonomy: A paper presented at at two-day workshop at UPI Bandung, Indonesia

Benson, P. (2012). Autonomy in language learning, learning and life, Hong Kong: Institute of Education.

Borg, S. \& Al Busaidi, S. (2012). Learner autonomy: English language teachers' beliefs and practices. United Kingdom: British Council.

Gardner, D., ed. (2011). Fostering Autonomy in Language Learning. Gaziantep: Zirve University. Retrieved from http://ilac2010.zirve.edu.tr

Gay, L. R., Mills, G. E., \& Airasian, P. W. (2009). Educational research, competencies for analysis and applications. United States: Pearson International.

Kamberi, L. (2013). Promoting learner autonomy in foreign language learning by using student journals. Proceeding of The First International Interdisciplinary Conference (pp. 408-412). Azores, Portugal.

Kesli, Y. (2015). Effects of task-based instruction of reading comprehension of Turkish EFL learners. International Journal of English Language Teaching, 3(2), 23-37. Retrieved from www.eajournals.org.

Kim, H. J. (2014). The use of technology for learner autonomy in language classroom. ITBE LinkFall 2014, 42(3).

Kumaravadivelu, B. (2003). Beyond Methods: Macrostrategies for Language Teaching. London: Yale University Press.

Lambert, V. A. \& Lambert, C. E. (2012). Qualitative descriptive research: An acceptable design. Pacific Rim International Journal of Nursing Research, 16(4), 255-256.

Lengkanawati, N. S. (2016). Teachers' beliefs about learner autonomy and its implementation in Indonesian EFL settings. In Barnard, $\mathrm{R}$ and and J. Li (eds), Language Learner Autonomy: Teachers' Beliefs and Practices in Asian Contexts. (pp. 134-149). Phnom Penh: CAMTESOL.

Dam, L. (2008). In-service teacher education for earner autonomy. IATEFL Learner Autonomy SIG, 20-28.

Ramirez, D. M. I. (2014). Developing learner autonomy through project work in an English for specific purposes. Class HOW, 21(2), 5473. Retrieved from http://dx.doi.org/10.19183/how.21.2.4

Rao, Z. (2012). Helping Chinese EFL students develop learner autonomy through Portfolio. Reflections on English Language Teaching, 5(22), 113-122. Retrieved from www.nus.edu.sg on March 13, 2015. Rukim, U. (2010). Pembelajaran masih berpusat pada guru. sulitkah mengubahnya? A blog post. Retrieved March 13, 2015 from http://urip.wordpress.com/2010/12/07/pembela jaran-masih-berpusat-pada-guru/.

Sandelowski, M. (2000). Focus on research methods-whatever happened to qualitative description?. Research in nursing and health, 23(4), 334-340. Retrieved on January $6^{\text {th }}, 2017$ from http://onlinelibrary.wiley.com/doi/10.1002/109 8-240X(200008)23:4\%3C334::AIDNUR9\%E3.0.CO2;2-G/abstract.

Shahsavari, S. (2014). Efficiency, feasibility and desirability of learner autonomy based on teachers. and learners point of views. Theory and Practice in Language Studies, 4(2), 271.

Silverman, D. (2005). Doing qualitative research: A practical handbook ( $2^{\text {nd }}$ Ed.). London: Sage Publications Ltd.

Thorne, S., Kirkham, S. R., \& MacDonald-Emes, J. (1997). Focus on qualitative methods. Interpretive description: a noncategorical qualitative alternative for developing nursing knowledge. Research in nursing \& health, 20(2), 169-177.

Wang, D. (2011). The dilemma of time: Studentcentered teaching in the rural classroom in China. Teaching and Teacher Education, 27(1), 157-164. 